\title{
Aspergillus niger Katalazının Üretimi, Üçlü-Faz Ayırma ile Saflaştırılması ve Biyokimyasal Karakterizasyonu
}

\author{
Eda BAYKAL SARI1 (D), Yonca YÜZÜGÜLLÜ KARAKUŞ*2 (iD)
}

${ }^{1}$ Kocaeli Üniversitesi, Fen Bilimleri Enstitüsü, Biyoloji Bölümü, 41001, Kocaeli, Türkiye

${ }^{2}$ Kocaeli Üniversitesi, Fen Edebiyat Fakültesi, Biyoloji Bölümü, 41001, Kocaeli, Türkiye

(Alınış / Received: 02.05.2019, Kabul / Accepted: 23.12.2019, Online Yayınlanma / Published Online: 20.04.2020)

\author{
Anahtar Kelimeler \\ Aspergillus niger, \\ Katalaz, \\ Üçlü-faz ayırma sistemi, \\ Oksidaz, \\ Peroksidaz
}

Özet: Bu çalışmada Aspergillus niger katalazının üretimi, saflaştırılması ve karakterize edilmesi amaçlanmıştır. Buna göre 1 litrelik YpSs sıvı büyüme ortamında $37^{\circ} \mathrm{C}$ ve $155 \mathrm{rpm}$ çalkalama hızında büyütülen $A$. niger'den 7. günde ham enzim ekstraktı elde edilmiştir. Katalaz enzimi üçlü-faz ayırma (TPP) tekniği ile saflaştırılmıştır. Bunun için $\% 80(\mathrm{w} / \mathrm{w})$ amonyum sülfat içeren ve ham ekstrakt:t-butanol oranı 1:1.5 olacak șekilde $\mathrm{pH}$ 7.0'da hazırlanan sistemden enzim \%263 verim ile 7.9 kat saflaştırılmıştır. $\mathrm{Km}_{\mathrm{m}}$ değeri (21.4 mM), optimum reaksiyon sicaklığı $\left(50^{\circ} \mathrm{C}\right)$ ve optimum reaksiyon pH'sı (6.0) belirlenmiştir. Kararlılık testleri, enzimin geniş $\mathrm{pH}$ (4.0-9.0) aralığında dayanıklı kalabildiğini göstermiștir. Ayrıca katalaz aktivitesinin \%7.5'lik (v/v) etanol varlı̆̆ında yaklaşı \% $77^{\prime}$ sinin korunduğu gözlenmiștir. Bununla birlikte, esas fonksiyonunun yanında 4-metil katekol ve katekol gibi fenolik bileşikleri peroksitten bağımsız olarak okside edebilmiştir. Sonuç olarak, A. niger'den katalaz enziminin geleneksel kromatografi yöntemi yerine zamandan tasarruf sağlayan, maliyeti ucuz ve kullanımı oldukça kolay olan üçlü faz sistemleri ile saflaştırılabildiği görülmektedir. Enzimin sahip olduğu biyokimyasal özellikleri ( $\mathrm{pH}$ ve etanol kararlılığı ve ikincil oksidaz aktivite varlığı), çeşitli endüstriyel uygulama alanlarında avantaj sağlayabilir.

\section{Production, Purification of Aspergillus niger Catalase by Three-Phase Partitioning and Its Biochemical Characterization}

\author{
Keywords \\ Aspergillus niger, \\ Catalase, \\ Three-phase partitioning, \\ Oxidase, \\ Peroxidase
}

\begin{abstract}
In this study, it was aimed to produce, purify and characterize catalase enzyme from Aspergillus niger. For that purpose, the cells of $A$. niger were grown at $37^{\circ} \mathrm{C}$ and $155 \mathrm{rpm}$ in 1 liter YpSs broth media and on the $7^{\text {th }}$ day of cultivation the crude enzyme extract was obtained from the growth media. Catalase enzyme was purified by three-phase partitioning method. Accordingly, the system prepared by $80 \%(\mathrm{w} / \mathrm{w})$ ammonium sulfate saturation at $\mathrm{pH} 7.0$ with 1:1.5 (v/v) ratio of crude extract to t-butanol gave 7.9 -fold purification with $263 \%$ activity recovery. The $\mathrm{K}_{\mathrm{m}}$ value $(21.4 \mathrm{mM})$, the optimum reaction temperature $\left(50^{\circ} \mathrm{C}\right)$ and the optimum reaction $\mathrm{pH}(6.0)$ were determined. Stability tests indicated that the enzyme can remain its activity in a broad $\mathrm{pH}$ (4.0-9.0) range. Additionally, it was observed that about $77 \%$ of initial catalase activity was maintained in the presence of $7.5 \%(\mathrm{v} / \mathrm{v})$ ethanol. Besides its main function, it can also oxidase some phenolic compounds like 4-methyl catechol and pyrocatechol in a peroxide-independent way. As a consequence, it was seen that the catalase enzyme can be purified from A. niger by a three-phase partitioning system known as a time-effective and inexpensive system and very easy to use rather than a conventional chromatography. Its biochemical properties ( $\mathrm{pH}$ and ethanol stabilities and presence of a secondary oxidase activity) can provide advantages in various industrial applications.
\end{abstract}




\section{Giriş}

Katalazlar (E.C. 1.11.1.6) antioksidan etkilerini hücredeki fazla hidrojen peroksidin $\left.\mathrm{H}_{2} \mathrm{O}_{2}\right)$ moleküler oksijen ve suya parçalanmasını sağlayarak gösterirler. Genel olarak katalazları üç gruba ayırabiliriz: Monofonksiyonel "hem" grubu içeren katalazlar, Katalaz-peroksidazlar ve Demir/hem içermeyip Mn içeren katalazlar [1]. Aspergillus türlerinde farklı sayıda ve çeşitte katalaz enzimi üretilmektedir. Genel olarak Aspergillus'larda bir adet katalaz-peroksidaz enzimi (miselyumda) bulunur. Diğer yandan monofonksiyonel katalazlar (miselyum ve konidyada bulunan) bir veya daha fazla sayıda olabilir [2-4].

A. niger ticari katalaz enzim kaynaklarından biri olmakla birlikte bu küfte en az dört farklı katalaz enziminin üretildiği bulunmuştur. Bunlardan ikisinin glukoz oksidaz enziminin varlığına bağlı olarak üretildiği rapor edilirken diğer iki katalazın Neurospora crassa katalazı (monofonksiyonel) ile genetik benzerlik taşıdığı belirtilmiştir [5]. Ancak $A$. niger'de gözlenen katalaz enzimlerinin kinetik özellikleri henüz araştırılmamıştır.

Bu çalışmada, A. niger katalazının üretimi, Üçlü-Faz Ayırma Sistemi (Three-Phase Partitioning-TPP) ile saflaştırılması ve biyokimyasal karakterizasyonu hedeflenmiştir. TPP proteinlerin bozulmadan sıvı fazda kalması için uygun bir ortam sağlamasının yanı sıra işlem süresinin kısa olması, enzimin yüksek geri kazanımla ve düşük maliyette saflaştırılması gibi ayrıcalıklara sahiptir. Sistem, ham enzim ekstraktına amonyum sülfat (tuz) ve t-butanol (organik çözücü) eklenmesinden oluşur. Sonuçta iki ayrı sıvı faz (üstte alkol içeren faz ve altta tuzlu sulu faz) meydana gelir. Amonyum sülfat, proteinlerin "salting-out" etkisiyle dereceli olarak çökmelerini sağlayan bir tuzdur. Butanol ise istenmeyen bileşiklerin (düşük molekül ağırlı̆̆ına sahip lipid ve fenolik maddeler) biyomoleküllerden seçici olarak uzaklaştırılmasını sağlar. Düşük hızda uygulanan santrifüj ile proteinler pellete (ara faza) geçer. Ara fazın tamponda tekrar çözünmesiyle spesifik ve toplam aktivite geri kazanılır, bazen de artar. TPP'nin en önemli avantajı büyük ve küçük ölçekli bütün çalışmalara uygulanabilmesidir. Diğer saflaştırma yöntemleri ile kıyaslandığında; harcanan amonyum sülfat miktarı, protein saflaştırmada ara işlemlerden biri olan tuzla çöktürme işlemine göre çok düşük olacağından ve geri kazanımının da mümkün olduğu düşünülürse, maddi açıdan oldukça makul bir maliyet tablosu ortaya çlkmaktadır [6]. TPP, günümüzde birçok biyomolekülün saflaştırılmasında kullanılmaktadır. Bunlara örnek olarak invertaz (Solanum tuberosum) [7], pektinaz (Lycopersicon esculentum) [8], $\beta$ galaktozidaz (Cicer arietinum) [9], proteaz inhibitörü (Eleusine coracana) [10], tripsin inhibitörü (Glycine $\max$ ) [11], $\alpha$-galaktozidaz (Solanum muricatum) [12]ve ksilinaz (A. niger) [13] verilebilir.
Literatürde katalazların farklı mikrobiyal kaynaklardan saflaştırılmasına yönelik raporlar mevcuttur; ancak küflerden katalaz eldesi üzerine yapılan çalışmalar sınırlıdır [14]. Bu çalışmalar incelendiğinde çoğunlukla kromatografik yöntemlerin kullanıldığı görülmektedir [15-17]. Dolayısıyla, katalazların küflerden TPP ile saflaştırılmasına yönelik herhangi bir çalışma bulunmamaktadır.

\section{Materyal ve Metot}

\subsection{Mikroorganizma ve kültür hazırlanması}

Küfe ait spor süspansiyonlarını hazırlamak amacıyla örnek PDA'da (Patates Dekstroz Agar, Potato Dextrose Agar) $30^{\circ} \mathrm{C}$ sicaklıkta 7 gün süreyle büyütülmüştür. Agar üzerinde gelişen sporlar 30 ml'lik steril \%0.01 (v/v) Tween 80 içeren çözelti içine alınarak spor sayımı Petroff - Hausser Lamı kullanılarak gerçekleştirilmiştir [18]. Daha sonra spor süspansiyonları steril Tween 80 içeren çözelti ile ml'sinde 1 milyon spor içerecek şekilde seyreltilmiş ve $\% 80$ (v/v) gliserol eklenerek $-80^{\circ} \mathrm{C}^{\prime}$ de muhafaza edilmiştir.

Küfün büyütülmesi için örneğe ait $100 \mu$ l'lik spor süspansiyonu $\left(10^{6} \mathrm{spor} / \mathrm{ml}\right) 20 \mathrm{ml} l i k$ öncü büyüme ortaminda canlandırıldıktan sonra 2000 ml'lik erlenler içerisinde $1000 \mathrm{ml}$ hazırlanan besiyerine $(10$ g/l glukoz, $0.5 \mathrm{~g} / \mathrm{l} \mathrm{MgSO}_{4} .7 \mathrm{H}_{2} \mathrm{O}, 1 \mathrm{~g} / \mathrm{l} \mathrm{K}_{2} \mathrm{HPO}_{4}$ ve $4 \mathrm{~g} / \mathrm{l}$ maya ekstraktı) aktarılmış ve 10 gün boyunca 155 rpm'de inkübasyona bırakılmıștır [19]. Katalaz üretiminin optimizasyonu için isı şoku ile oksidatif stres uygulamaları gerçekleştirilmiştir. Isı şoku yaratmak amacıyla kültürler $37,42,45,50$ ve $55^{\circ} \mathrm{C}$ sıcaklık derecelerinde büyütülmüştür [20]. Oksidatif stres için ise ön kültürün aktarıldığı ana büyüme ortamına $\mathrm{H}_{2} \mathrm{O}_{2}, 0.1 \mathrm{mM}, 0.5 \mathrm{mM}, 1 \mathrm{mM}$ ve $2 \mathrm{mM}$ derişimlerinde katalaz aktivitesinin optimum üretildiği günde (7. gün) her 30 dakikada bir eklenerek 2 ila 6 saat $(2,3,4,5$ ve 6 saat) inkübe edilmiştir [21].

\subsection{Biyokütle tayini}

Biyokütle tayini için 24 saatte bir 50'şer ml örnek kültür ortamından toplanarak hücreler Whatman filtre kağıdından (No:1) filtrasyon yolu ile uzaklaştırılmıştır. Süzülmüş ortam sıvısı (süpernatan), enzim aktivite ve protein miktar tayinlerinde kullanılmıștır. Filtre kağıdında bulunan hücreler ise distile su ile ylkandıktan sonra kuru ağırlığının belirlenmesi üzerine $100^{\circ} \mathrm{C}$ 'de sabit bir ağırlı̆̆a ulaşıncaya kadar bekletilmiş ve biyokütle tayininde kullanılmıştır [22]. Biyokütleden ayrılan ortam sıvisı, ham enzim ekstraktı olarak isimlendirilmiş, saflaştırma ve katalitik aktivite tayininde kullanılmıștır. 


\subsection{Enzim aktivite tayini}

Katalaz aktivitesi spektrofotometrik yöntemle ölçülmüştür. 1 ml'lik reaksiyon sıvısı, 10 mM $\mathrm{H}_{2} \mathrm{O}_{2}$ solüsyonundan $2.9 \mathrm{ml}$ ve enzim solüsyonundan 0.1 $\mathrm{ml}(\mathrm{pH}$ 7.0) konularak hazırlanmıştır. Reaksiyon sıcaklığı $25^{\circ} \mathrm{C}^{\prime} y e$ ayarlandıktan sonra hidrojen peroksidin kaybolma hızı 240 nm'de ölçülerek hesaplanmıştır. 1 Ünite aktivite, $1 \mu$ mol $\mathrm{H}_{2} \mathrm{O}_{2}{ }^{\prime} \mathrm{i} 1$ dakikada parçalayabilen enzime karşılık gelmektedir [15]. Enzim aktivite analizlerinde "kontrol" olarak reaksiyon ortamına enzim yerine tampon çözelti eklenerek aktivite ölçümleri yapılmıştır.

\subsection{Protein miktar tayini}

Protein konsantrasyonu Bradford Metoduna göre belirlenmiş; standart grafiğin çizilmesinde protein olarak sığır serum albümini kullanılmıştır [23].

\section{5. Üçlü-faz ayırma sistemi}

Çalışmada, 2 ml ham enzim ekstraktı, farklı amonyum sülfat doygunluklarına $(\% 40, \% 50, \% 60, \% 70, \% 80$ ve $\% 90, \mathrm{w} / \mathrm{w}$ ) getirilmiş ve karışıma farklı ham enzim ekstrakt/t-bütanol oranları (1.0:0.5, 1.0:1.0, 1.0:1.5 ve 1.0:2.0) sağlanacak şekilde t-butanol eklenmiştir. Sistem pH'sı farklı pH'larda (4.0-9.0) hazırlanmıştır. Karışım oda sıcaklığında 1 saat bekletildikten sonra 4500 rpm'de 10 dak santrifüjlenerek faz ayrımları gözlenmiştir [7, 24]. Proteinin bulunmasının beklenmediği butanolce zengin üst faz dikkatlice pipetlenerek ortamdan uzaklaştırıldıktan sonra orta ve alt fazlar toplanarak $100 \mathrm{mM}$ sodyum fosfat tampon çözeltisine ( $\mathrm{pH}$ 7.0) karşı bir gece diyaliz edilmiștir. Diyaliz sonrası orta ve alt fazlarda aktivite ve protein değerleri yukarıda anlatılan şekilde spektrofotometrik yöntemle tespit edilmiştir.

Spesifik bir enzimin TPP ile ayrımının analizi aşağıda verilen parametrelerin değerlendirilmesi ile mümkündür [25]:

Spesifik aktivite (SA), $1 \mathrm{mg}$ protein başına düşen enzim ünitesidir. Her bir basamaktaki enzimatik aktivitenin $(\mathrm{U} / \mathrm{ml})$ yine her basamaktaki protein konsantrasyonuna $(\mathrm{mg} / \mathrm{ml})$ bölünmesiyle hesaplanır. Saflaştırma katsayısı (PF), herhangi bir fazda ölçülen enzime ait spesifik aktivitenin ham enzim ekstraktında ölçülen enzim aktivitesine oranıdır. Protein geri kazanım değeri $(\% \mathbf{R})$ ise herhangi bir fazdaki enzim aktivite değerinin sisteme eklenen enzimin başlangıçtaki aktivitesine oranıdır.

\subsection{Sodyum dodesil sülfat poliakrilamid jel elektroforezi (SDS-PAGE)}

Katalaz enzim saflığının kontrolü SDS-PAGE analizi ile yapılmıştır. Buna göre elektroforez, Bio-Rad MiniProtean sistemi kullanılarak; \%5 (v/v) yükleme jeli ve $\% 15 \quad(\mathrm{v} / \mathrm{v})$ ayırma jeli hazırlanarak gerçekleştirilmiştir [26]. Protein markör'ü olarak BioRad Low Range (14-97 kDa) kullanılmıștır. Elektroforez 200 V'da yaklaşık 50 dak yürütülerek gerçekleştirilmiş ve yürütülen jeller elde edilen protein konsantrasyonuna göre gümüş boyama [27] ile boyanmıştır.

\subsection{Sıcaklık ve pH'nın enzim aktivitesi üzerine etkisi}

Sıcaklığın enzim üzerine etkisini incelemede $30^{\circ} \mathrm{C}-$ $70^{\circ} \mathrm{C}$ sıcaklık aralığında aktivite ölçümleri gerçekleştirilmiştir. Enzim aktivitesi ( $\%$ Bağll Aktivite) ve reaksiyon sıcaklık değerleri arasında çizilen grafik ile enzimin optimum reaksiyon sıcaklık değeri belirlenmiştir. Termal kararlılık tayini için ise aynı miktarda protein ihtiva eden enzim örnekleri 60 dak boyunca farklı sicaklıklarda $(30,40,50,60$ ve $70^{\circ} \mathrm{C}$ ) inkübe edilip ardından standart aktivite ölçüm değerinde $\left(25^{\circ} \mathrm{C}\right.$ 'de $)$ aktivite tayinleri yapılmıștır.

Farklı pH değerlerinin katalitik aktivite üzerindeki etkilerini belirlemek için 4.0 ila 9.0 arasında değişen farklı pH'larda (4.0, 5.0, 6.0, 7.0, 8.0 ve 9.0) standart koşullar altında spektrofotometrede (Cary60, Agilent) enzim aktivite ölçümü alınmıştır. pH 4.0 - 5.0 arasındaki reaksiyonlar için $100 \mathrm{mM}$ sitrat tampon çözeltisi, pH 6.0 ila 7.0 için $100 \mathrm{mM}$ sodyum fosfat tampon çözeltisi, pH 8.0 için $100 \mathrm{mM}$ tris tampon çözeltisi ve pH 9.0 için $100 \mathrm{mM}$ glisin sodyum hidroksit tampon çözeltileri kullanılmıştır. pH'nın enzim dayanıklılı̆̆ üzerine etkisini test etmek için ise aynı $\mathrm{pH}$ aralığı arasında hazırlanmış tampon çözeltilerde enzim örnekleri 1 saat inkübe edildikten sonra katalaz aktivite ölçümleri yapılmıştır [28].

\subsection{Organik çözücülerin enzim aktivitesi üzerine etkisi}

Organik çözücülere karşı katalaz enziminin dayanıklılık derecesini incelemek amacıyla, aseton, etanol, dimetil sülfoksit (DMSO) ve metanol son konsantrasyonları $\% 2.5,5,7.5,10,15,20$ ve 25 (v/v) olacak şekilde reaksiyon karışımına direk eklenmiş [22] ve katalaz aktivite tayini yukarıda açılkanan şekilde gerçekleștirilmiştir.

\subsection{Kinetik parametrelerin belirlenmesi}

A. niger'den saflaşturılan katalaz örneği $0.1-70 \mathrm{mM}$ arasındaki farklı konsantrasyonlarda hidrojen peroksit substrat olarak kullanılarak aktiviteleri ölçülmüş; $K_{m}$ ve $V_{\max }$ değerleri Lineweaver-Burk Plot ile hesaplanmıştır [29].

\subsection{Oksidaz/peroksidaz substrat özgüllüğü}

Katalaz enziminin olası ikincil oksidatif/peroksidatif aktivite özelliği spektrofotometrik yöntemle test edilmiştir. Buna göre (saf) enzim aktivitesi farklı 
oksidaz/peroksidaz substratları varlı̆̆ında analiz edilmiştir. Kullanılan substratlar arasında pirogallol (430 nm), hidrokinon (440 nm), ABTS (2,2'-azinobis(3-ethylbenzothiazoline-6-sulphonic acid, 420 $\mathrm{nm}$ ), guaiakol (465 $\mathrm{nm}$ ) ve L-tirozin (475 $\mathrm{nm}$ ) yer almaktadır $[22,30]$.

\subsection{1. İstatistiksel analiz}

Denemeler farklı zaman dilimlerinde üç kez tekrar edilmiştir. Veriler arasındaki istatistiksel farklılığın derecesi $(\mathrm{p}<0.05)$ veri setine göre Duncan veya Tukey HSD çoklu karşılaştırma testine göre belirlenmiştir. İstatistiksel analiz IBM SPSS Statistics 19 programı kullanılarak gerçekleştirilmiştir.

\section{Bulgular}

\subsection{Zamana bağlı katalaz üretimi}

$\% 1(\mathrm{w} / \mathrm{v})$ glukoz içeren besi ortamında 10 gün boyunca büyütülen $A$. niger'de ölçülen hücre dişı katalaz üretimi ve biyokütle tayin sonuçları Şekil 1'de gösterilmektedir. Buna göre, küfün büyümesi sırasında gözlenen Logaritmik faz altıncı güne kadar sürmüştür. Diğer yandan küf 6. günde durağan faza girmiş ve 8. güne kadar bu fazda kalmıştır. Katalaz aktivitesi ise küf büyümesine paralel olarak artış göstermiş; en yüksek değerine küf durağan fazda (7. gün) iken ulaşmıştır.
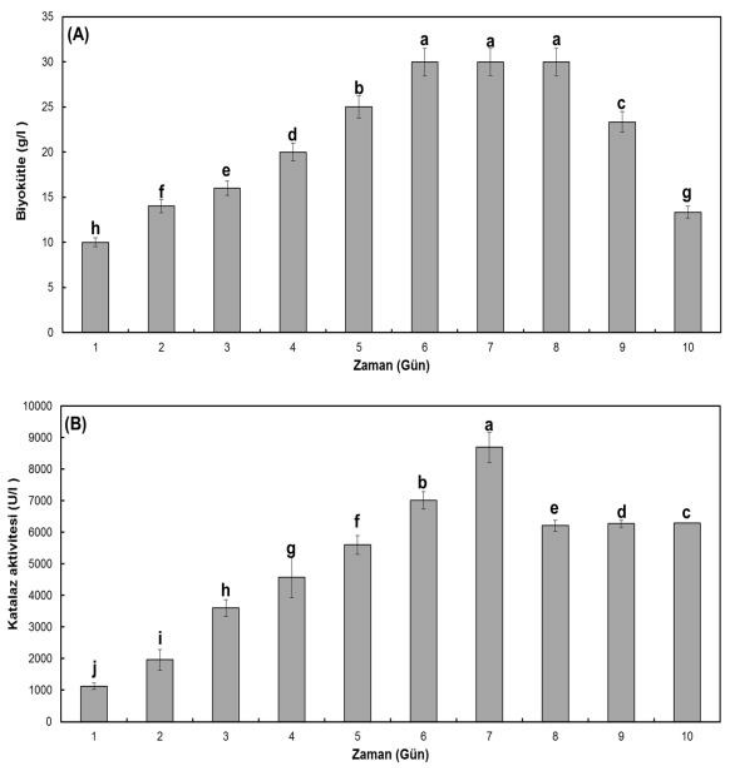

Şekil 1. A. niger'e ait (A) biyokütle (g/l) ve (B) katalaz (U/l) aktivite grafiği. A. niger, karbon kaynağı olarak \%1 (w/v) glukoz içeren 1 litrelik YpSs büyüme ortamında büyütülmüştür. Hata çubukları standart sapmayı ifade etmektedir. Aynı harfleri taşıyan değerler arasında Duncan çoklu karşılaştırma testine göre istatistiki önemli fark yoktur $(\mathrm{p}<0.05)$.

\subsection{Katalaz üretiminin optimizasyonu}

Katalaz enzim üretiminin optimizasyonunda eşit miktarda spordan canlandırma yapılarak büyütülen $A$. niger'de sıcaklığın ve $\mathrm{H}_{2} \mathrm{O}_{2}$ 'nin katalaz üretimine olumlu/olumsuz etkileri araştırılmıştır. Buna göre, katalaz aktivitesinin en yüksek bulunduğu değer küfün $37^{\circ} \mathrm{C}$ sicaklıkta (Tablo 1) büyütüldüğü ve $\mathrm{H}_{2} \mathrm{O}_{2}$ 'nin büyüme ortamına eklenmediği (Şekil 2) koşullarda ölçülmüştür.

Tablo 1. Sıcaklığın katalaz üretimine etkisi

\begin{tabular}{lc}
\hline Sicaklık $\left({ }^{\circ} \mathrm{C}\right)$ & Katalaz aktivitesi (U/l) \\
\hline 30 & $8688 \pm 480 \mathrm{~b}$ \\
$\mathbf{3 7}$ & $\mathbf{9 1 2 8 \pm 1 4 8 a}$ \\
45 & $6269 \pm 937 \mathrm{c}$ \\
47 & $-\mathrm{d}$ \\
50 & $-\mathrm{d}$ \\
55 & $-\mathrm{d}$ \\
\hline Bir kritere ait kolondaki farklı harfler, Duncan çoklu \\
karşılaștırma testine göre istatistiksel olarak ortalamalar \\
arasındaki önemli farklılıkları göstermektedir (p<0.05). \\
Standart sapma $( \pm S S)$.
\end{tabular}

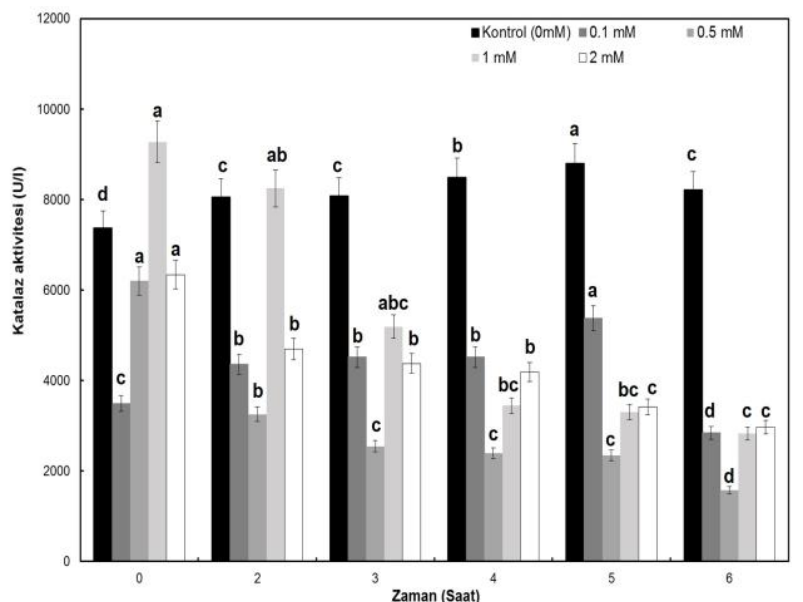

Şekil 2. Hidrojen peroksit $\left(\mathrm{H}_{2} \mathrm{O}_{2}\right)$ konsantrasyonun katalaz aktivite üzerine etkisi. $A$. niger, karbon kaynağı olarak $\% 1$ $(\mathrm{w} / \mathrm{v})$ glukoz içeren 1 litrelik YpSs sıvı büyüme ortamında büyütülmüștür. $\mathrm{H}_{2} \mathrm{O}_{2}$, büyüme ortamına enzim üretiminin optimum olduğu yedinci gününde 30 'ar dakika arayla eklenmiştir. Hata çubukları standart sapmayı ifade etmektedir. Aynı harfleri taşıyan değerler arasında Tukey HSD çoklu karşılaştırma testine göre istatistiki önemli fark yoktur $(\mathrm{p}<0.05)$.

\subsection{Katalaz enziminin üçlü-faz ayırma sistemi ile kısmi saflaştırılması}

A. niger'den elde edilen süpernatandan (1 mg protein; $79 \mathrm{U} / \mathrm{mg}$ ) katalaz enziminin saflaştırılmasında kullanılan TPP sistemi Bölüm 2.5'te açıklandığı şekilde uygulanmıştır. Bu amaçla, farklı derişimlerde hazırlanan amoyum sülfat ve t-butanol çözeltileri kullanılmıştır. Öncelikle optimum amonyum sülfat konsantrasyonunu belirlemek için ham ekstrakt/tbutanol oranı 1:1 olan farklı amonyum sülfat konsantrasyonları ile hazırlanan sulu üçlü faz sistemlerinde $A$. niger katalazının dağılımı gerçekleştirilmiş ve sonuçlar Tablo 2'de verilmiştir. Buna göre $A$. niger katalazı hazırlanan faz kompozisyonlarının çoğunda dağılma göstermiştir. En yüksek saflaştırma katsayısı (7.0) ve aktivite geri kazanım değerleri (\%206), \%80 (w/w) amonyum sülfat ile hazırlanan sistemin ara fazında ölçülmüştür. 
Tablo 2. Amonyum sülfat (AS) konsantrasyonunun TPP sisteminde katalaz ayrımına etkisi

\begin{tabular}{|c|c|c|c|c|c|c|}
\hline & & $\mathrm{SA}(\mathrm{U} / \mathrm{mg})$ & $\begin{array}{c}\text { Toplam } \\
\text { aktivite (U) }\end{array}$ & $\begin{array}{c}\text { Toplam protein } \\
\text { miktarı (mg) }\end{array}$ & $\mathrm{PF}$ & $\% \mathrm{R}$ \\
\hline Ham ekstrakt & & 79 & 79 & 1.0 & 1.0 & 100 \\
\hline \multirow{3}{*}{$\% 40(w / w)$ AS } & Üst faz* & - & - & - & - & - \\
\hline & Ara faz & - & - & 0.1 & - & - \\
\hline & Alt faz & 316 & 151 & 0.5 & 4.0 & 191 \\
\hline \multirow{3}{*}{$\% 50(w / w)$ AS } & Üst faz* & - & - & - & - & - \\
\hline & Ara faz & 24 & 13.4 & 0.6 & 0.3 & 17 \\
\hline & Alt faz & 71 & 40 & 0.6 & 0.9 & 51 \\
\hline \multirow{3}{*}{$\% 60(w / w)$ AS } & Üst faz* & - & - & - & - & - \\
\hline & Ara faz & 103 & 104 & 0.9 & 1.3 & 132 \\
\hline & Alt faz & 270 & 27 & 0.1 & 3.4 & 34 \\
\hline \multirow{3}{*}{$\% 70(w / w)$ AS } & Üst faz & 97 & 67 & 0.7 & 1.2 & 85 \\
\hline & Ara faz & 75 & 13 & 0.2 & 3.0 & 160 \\
\hline & Alt faz ${ }^{*}$ & - & - & - & - & - \\
\hline \multirow{3}{*}{$\% 80(w / w)$ AS } & Üst faz & - & - & 0.3 & - & - \\
\hline & Ara faz & 540 & 162 & 0.3 & 7.0 & 206 \\
\hline & Alt faz & 79 & 32 & 0.4 & 1.0 & 40 \\
\hline \multirow{3}{*}{$\% 90(w / w)$ AS } & Üst faz* & - & - & - & - & - \\
\hline & Ara faz & 383 & 115 & 0.3 & 5.0 & 146 \\
\hline & Alt faz* & - & - & - & - & - \\
\hline
\end{tabular}

*Bu fazlarda enzim aktivite ve protein miktar tayinleri negatif sonuç vermiştir. SA: spesifik aktivite, PF: Saflaştırma katsayısı, \%R: Enzim aktivite geri kazanımı. Sistem pH'sı 6.0, sıcaklığı ise $25^{\circ} \mathrm{C}^{\prime}$ dir.

Daha sonra amonyum sülfat konsantrasyonu $(80 \%$, $\mathrm{w} / \mathrm{w}$ ) sabit tutularak farklı ham ekstrakt/t-butanol oranlarında hazırlanmıș sistemlerde spektrofotometrik analizler gerçekleştirilmiştir. Bir önceki basamakta enzimin seçici olarak ara fazda toplandığı belirlendiğinden sadece ara faz sonuçları değerlendirilmiştir. Tablo 3 'de belirtildiği üzere enzimin saflık derecesi $1: 1,1: 1.5$ ve $1: 2$ sistemlerinde 1:0.5'e göre daha iyi çılkmıştır. 1:1.5 oranında hazırlanan sistemde maksimum saflaştırma katsayısı (7.7) ve aktivite geri kazanımı (\%212) elde edilmiștir. $\mathrm{Bu}$ sebeple, ileriki denemeler ham ekstrakt:t-butanol oranının 1:1.5 olduğu sistemlerde yapılmıştir.

Tablo 3. Ham ekstrakt/t-butanol oranının TPP sisteminde katalaz ayrımına etkisi

\begin{tabular}{|c|c|c|c|c|c|}
\hline & $\begin{array}{c}\text { SA } \\
(\mathrm{U} / \mathrm{mg})\end{array}$ & $\begin{array}{c}\text { Toplam } \\
\text { aktivite } \\
\text { (U) }\end{array}$ & $\begin{array}{c}\text { Toplam } \\
\text { protein } \\
\text { miktarı } \\
(\mathrm{mg}) \\
\end{array}$ & $\mathrm{PF}$ & $\% \mathrm{R}$ \\
\hline $\mathrm{HE}$ & 79 & 79 & 1.0 & 1.0 & 100 \\
\hline $\begin{array}{l}\text { HE: t-but } \\
1.0: 0.5\end{array}$ & 158 & 96 & 0.6 & 2.0 & 121 \\
\hline $\begin{array}{l}\text { HE: t-but } \\
1.0: 1.0\end{array}$ & 540 & 162 & 0.3 & 7.0 & 206 \\
\hline $\begin{array}{l}\text { HE: t-but } \\
\mathbf{1 . 0 : 1 . 5}\end{array}$ & 611 & 168 & 0.3 & 7.7 & 212 \\
\hline $\begin{array}{l}\text { HE: t-but } \\
1.0: 2.0\end{array}$ & 466 & 161 & 0.3 & 5.9 & 204 \\
\hline
\end{tabular}

Optimum sistem pH'sını tayin etmek için ham ekstrakt $\% 80 \quad(\mathrm{w} / \mathrm{w})$ amonyum sülfatla doyurulduktan sonra sistem pH'si ayarlanmıștır. Tablo 4, farklı pH'larda hazırlanan sistemlerde ölçülen enzim aktivite ve miktar bulgularını göstermektedir. En yüksek saflaștırma katsayısı (7.9) ve aktivite geri kazanım değerleri (\%263), pH'sı 7.0 olan sistemde ölçülmüştür.

Tablo 4. TPP sistem pH'sının katalaz ayrımına etkisi

\begin{tabular}{lccccc}
\hline & SA & $\begin{array}{c}\text { Toplam } \\
\text { aktivite } \\
(\mathrm{U})\end{array}$ & $\begin{array}{c}\text { Toplam } \\
\text { protein } \\
\text { miktarl } \\
(\mathrm{mg})\end{array}$ & PF & $\% \mathrm{R}$ \\
\hline HE & 79 & 79 & 1.0 & 1.0 & 100 \\
pH 3.0 & 142 & 16 & 0.1 & 1.8 & 20 \\
pH 4.0 & 158 & 28 & 0.2 & 2.0 & 35 \\
pH 5.0 & 198 & 36 & 0.2 & 2.5 & 45 \\
pH 6.0 & 611 & 168 & 0.3 & 7.7 & 212 \\
pH 7.0 & $\mathbf{6 2 4}$ & $\mathbf{2 0 8}$ & $\mathbf{0 . 3}$ & $\mathbf{7 . 9}$ & $\mathbf{2 6 3}$ \\
pH 8.0 & 174 & 28 & 0.2 & 2.2 & 36 \\
pH 9.0 & 150 & 19 & 0.1 & 1.9 & 24 \\
\hline
\end{tabular}

HE: Ham ekstrakt, t-but: t-butanol, SA: spesifik aktivite, PF: Saflaştırma katsayısı, \%R: Enzim aktivite geri kazanımı. Sistem sıcaklığı $25^{\circ} \mathrm{C}^{\prime}$ dir.

\subsection{SDS-PAGE analizi}

TPP sistemi ile saflaştırılan katalaz enziminin saflığının kontrolü \%15'lik SDS-PAGE ile gerçekleștirilmiștir. Elektroforez sonrası jel, gümüș boyama metodu ile boyanmıştır. Şekil 3'de görüldügü üzere örneğe ait yaklaşık $87 \mathrm{kDa}$ civarında tek bir bant gözlenmiştir.

\subsection{A. niger katalazının biyokimyasal karakterizasyonu}

\subsubsection{Sıcaklığın enzim aktivitesi üzerine etkisi}

Sıcaklı̆̆ın enzim aktivitesi ve dayanıklılığı üzerine etkisinin incelenmesi denemelerinde TPP sistemi ile kısmen saflaştırılmış enzim kullanılmıştır. Optimum reaksiyon sıcaklığının belirlenmesi için enzim aktivite 
ölçümleri 30 ila $70^{\circ} \mathrm{C}$ arasında değişen sıcaklıklarda yapılmıștır. En yüksek aktiviteler $50-60^{\circ} \mathrm{C}$ arasında ölçülmüş olup maksimum aktivite değerine $50^{\circ} \mathrm{C}$ 'de ulaşılmıştır (Şekil 4A).

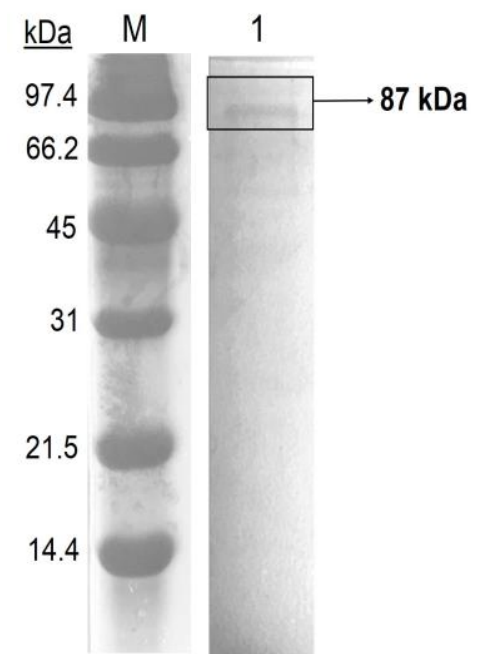

Şekil 3. A. niger'den TPP ile saflaştırılan katalazın SDSPAGE jel görüntüsü. M, protein markör (marker) (Bio-Rad Unstained SDS-PAGE Standards, Amerika); 1, \%80 (w/w) $\left(\mathrm{NH}_{4}\right)_{2} \mathrm{SO}_{4}$ konsantrasyonunda, 1:1.5 ham ekstrakt/tbutanol oranında ve $\mathrm{pH}$ 7.0'da hazırlanmıș sistemden izole edilen katalaz örneği.

Termal kararlılık testlerinde ise enzim yukarıda belirtilen sıcaklık aralığında yaklaşı 60 dak inkübe edildikten sonra örnekler $25^{\circ} \mathrm{C}$ ye (aktivite ölçüm sıcaklığl) soğutulmuş ve aktivite ölçümleri standart koşullarda $\left(\mathrm{pH} 7.0,25^{\circ} \mathrm{C}\right)$ gerçekleştirilmiştir. Şekil $4 B^{\prime}$ de görüldüğü üzere enzim $40^{\circ} \mathrm{C}^{\prime}$ de aktivitesini korumaktadır. Ancak $40^{\circ} \mathrm{C}^{\prime}$ den sonra aktivitede $\% 53$ 55 oranında kayıp gözlenmiştir.

\subsubsection{Ortam pH'sının enzim aktivitesi üzerine etkisi}

Katalaz enzimi için optimum reaksiyon pH değeri 6.0 olarak belirlenmiştir (Şekil 5A). Diğer yandan $\mathrm{pH}$ $7.0^{\prime} \mathrm{da}, \quad \mathrm{pH} \quad 6.0^{\prime} \mathrm{da}$ ölçülen aktiviteye göre yaklaşı \%82'sinin, pH $5.0^{\prime}$ da ise \%70'inin korunduğu gözlenirken 8.0 ve üzerindeki $\mathrm{pH}$ değerlerinde ise aktivitede hızlı bir düşüş olduğu görülmüştür.

Enzimin $\mathrm{pH}$ kararlılı̆̆ını tayin etmek için saflaştırılmış örnek pH'sı 4.0'dan 9.0'a kadar değişen farklı tampon çözeltilerde yaklaşık 60 dak bekletildikten sonra standart koşullarda $(\mathrm{pH}$ 7.0, $25^{\circ} \mathrm{C}$ ) aktivite analizleri yapılmıştır. Buna göre, katalaz enziminin aktivitesini en iyi koruduğu $\mathrm{pH}$ değeri 6.0'dır (Şekil 5B). Bu değerin üzerinde rezidüel aktivitede pH artışına bağlı olarak kademeli bir düşüş gözlense de bu düşüş en fazla \%77-97 arasındadır. Benzer șekilde düşük pH değerlerinde de aktivitenin \%63'ünden fazlasının korunduğu görülmektedir.
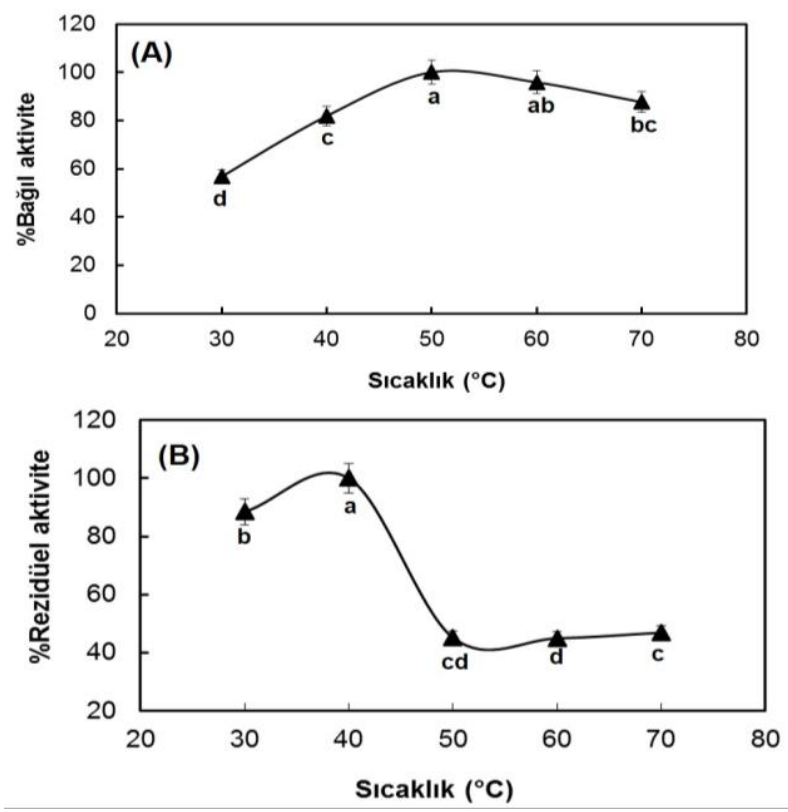

Şekil 4. Sıcaklığın A. niger katalaz (0.022 mg protein $/ \mathrm{ml})$ aktivitesi ve kararlılığına etkisi. Enzim aktivite ölçümlerinde $10 \mathrm{mM} \mathrm{H} \mathrm{H}_{2}$ ve $100 \mathrm{mM}$ Sodyum fosfat tampon çözeltisinden (pH 7.0) oluşan karışım kullanılmıştır. (A) Farklı reaksiyon sıcaklık değerlerinde ölçülen bağıl aktivite grafiği (B) Farklı sıcaklıklarda enzimin

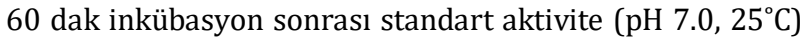
ölçümlerine dayalı rezidüel aktivite grafiği. Hata çubukları standart sapmayı ifade etmektedir. Aynı harfleri taşıyan değerler arasında Duncan çoklu karşılaştırma testine göre istatistiki önemli fark yoktur $(\mathrm{p}<0.05)$.
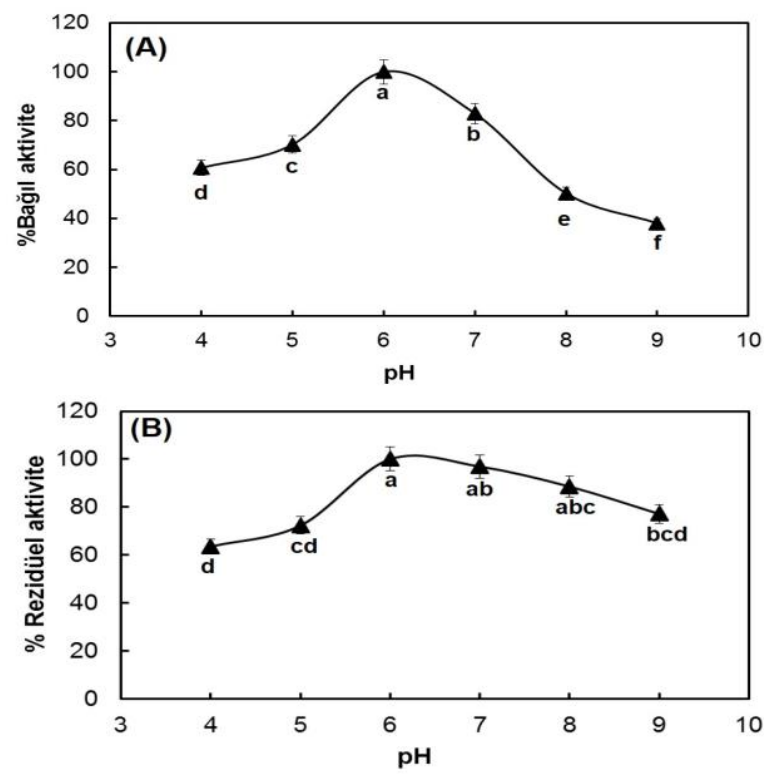

Şekil 5. Ortam pH'sının A. niger katalaz $(0.022 \mathrm{mg}$ protein/ml) aktivitesi ve kararlılığına etkisi. Enzim aktivite ölçümlerinde $10 \mathrm{mM} \mathrm{H} \mathrm{H}_{2}$ ve $100 \mathrm{mM}$ Sodyum fosfat tampon çözeltisinden (pH 7.0) oluşan karışım kullanılmıştır. (A) Farklı reaksiyon pH değerlerinde ölçülen bağıl aktivite grafiği (B) Farklı pH değerlerinde hazırlanan tampon çözeltilerde enzimin 60 dak inkübasyon sonrası standart aktivite $\left(\mathrm{pH} 7.0,25^{\circ} \mathrm{C}\right)$ ölçümlerine dayalı rezidüel aktivite grafiği. Hata çubukları standart sapmayı ifade etmektedir. Aynı harfleri taşıyan değerler arasında Duncan çoklu karşılaştırma testine göre istatistiki önemli fark yoktur $(\mathrm{p}<0.05)$. 


\subsubsection{Organik çözücülerin etkisi}

Biyotransformasyon uygulamalarında çoğunlukla organik çözücüler kullanılmaktadır [31]. Bu nedenle, biyokatalizör olarak katalazın bazı organik çözücüler varlığında aktivitesinde meydana gelebilecek olası değişiklikleri analiz etmek üzere enzim aktivite ölçümleri etanol, metanol, aseton ve DMSO varlığında yapılmıștır. Bulgular Tablo 5'de gösterilmektedir.

Organik çözücülerin eklendiği reaksiyon ortamlarında genel olarak çözücü konsantrasyonunun artışına bağlı olarak aktivitede kademeli olarak azalma gözlenmiştir. Kullanılan çözücüler içinde katalaz enzimini olumsuz yönde en fazla etkileyen asetondur. $\% 5(\mathrm{v} / \mathrm{v})$ ve üzeri konsantrasyonlarda aktivite tamamen inhibe olmuștur (Tablo 5). Diğer yandan etanol enzim aktivitesi üzerinde \%7.5'e (v/v) kadar önemli düzeyde bir azalmaya sebep olmamıştır. Fakat, \%10 (v/v) derişiminde reaksiyon ortamına eklendiğinde kontrole göre (çözücü eklenmemiş ortam) aktivitenin yaklaşı \% \%56 kadarı kaybolmuştur. Metanol ve DMSO eklenmesi ise \%2.5'luk (v/v) derişimlerinde aktivitenin yaklaşık yarısının kaybolmasına sebep olurken \%10'da (v/v) metanol enzimi tamamen inhibe etmiştir.

\subsection{4. $K_{m}$ ve $V_{\max }$ tayini}

A. niger katalazına ait $\mathrm{K}_{\mathrm{m}}$ ve $\mathrm{V}_{\max }$ değerlerinin hesaplanması için oluşturulan Lineweaver-Burk diyagramı Şekil 6'da verilmiştir. Enzimin hızını ve substratına olan afinitesini belirten bu değerlerin hesaplanması amacıyla katalaz enziminin substratı olan $\mathrm{H}_{2} \mathrm{O}_{2}{ }^{\prime}$ nin $0.1-70 \mathrm{mM}$ aralığındaki konsantrasyonlarında aktivite tayini yapıldı. Lineweaver-Burk diyagramından (1/S'ye karşı 1/V) $\mathrm{K}_{\mathrm{m}}$ ve $\mathrm{V}_{\max }$ değerleri sirasiyla $21.4 \mathrm{mM}$ ve 20.000 $\mu \mathrm{mol} / \mathrm{dak} / \mathrm{l}$ olarak belirlendi.

\subsubsection{Oksidatif/Peroksidatif substratların belirlenmesi}

A. niger katalazında diğer katalazlarda $[15,28,30$, 32, 33, 34, 35] olduğu gibi peroksitten bağımsız ikincil aktivitenin varlı̆̆ını araștırmak üzere farklı peroksidaz ve oksidaz substratlarına karşı aktivite analizleri gerçekleştirilmiştir. Elde edilen bulgular

Tablo 6'da gösterilmiștir. Buna göre A. niger'den izole edilen katalazın polifenol oksidaz (substrat ilgisi: 4metil katekol>katekol) aktivitesi gösterdiği bulunmuştur.

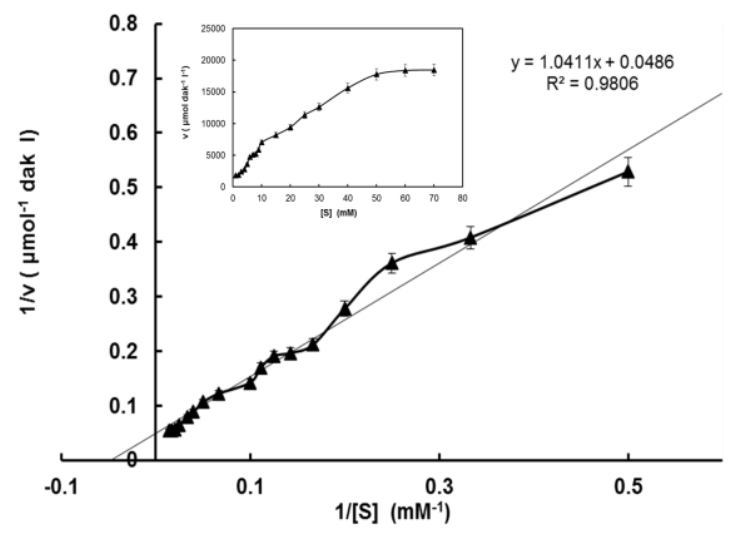

Şekil 6. Katalaz enziminin Lineweaver-Burk diyagramı (Substrat [S]: Hidrojen peroksit, $\mathrm{H}_{2} \mathrm{O}_{2}$ ) [29]. Ekli küçük resim, $\mathrm{H}_{2} \mathrm{O}_{2}$ konsantrasyonunun katalaz aktivitesine etkisini gösteren Michaelis-Menten grafiğini göstermektedir. Hata çubuklarl, Sigmaplot 14.0 (Systat Software Inc.) kullanarak hesaplanmış olup her bir verinin ortalamaya göre ne kadar uzaklıkta olduğunu göstermektedir.

Tablo 6. A. niger katalazının farklı oksidatif/peroksidatif substratlarına ilgisi ve $T$. versicolor lakkazı ile turp peroksidazıyla karșılaștırılması

\begin{tabular}{|c|c|c|c|}
\hline \multirow[b]{2}{*}{ Substrat $\left(\mathrm{mM}^{*}\right)$} & \multicolumn{3}{|c|}{$\begin{array}{l}\text { \%Bağıl Oksidatif/Peroksidatif } \\
\text { aktivite }\end{array}$} \\
\hline & $\begin{array}{l}\text { A. niger } \\
\text { katalazı }\end{array}$ & $\begin{array}{c}\text { T. versicolor } \\
\text { lakkazı }\end{array}$ & $\begin{array}{l}\text { Turp } \\
\text { peroksidazı }\end{array}$ \\
\hline $\begin{array}{l}\text { 4-Metil Katekol } \\
(100 \mathrm{mM})\end{array}$ & 100 & 3.4 & - \\
\hline $\begin{array}{l}\text { Katekol } \\
(100 \mathrm{mM})\end{array}$ & 1.8 & 0.02 & - \\
\hline $\begin{array}{l}\text { Pirogallol } \\
(285 \mathrm{mM})\end{array}$ & - & & 100 \\
\hline Guaicol & - & 28.4 & - \\
\hline $\begin{array}{l}\text { Guaicol } \\
(5 \mathrm{mM})\end{array}$ & - & 41.5 & - \\
\hline ABTS (5 mM) & - & 100 & - \\
\hline $\begin{array}{l}\text { Hidrokinon } \\
(100 \mathrm{mM})\end{array}$ & - & - & - \\
\hline $\begin{array}{l}\text { L-Tirozin } \\
(5 \mathrm{mM})\end{array}$ & - & - & - \\
\hline
\end{tabular}

Tablo 5. Organik çözücülerin katalaz aktivite üzerine etkisi

\begin{tabular}{|c|c|c|c|c|c|}
\hline Organik çözücü & $\% \mathrm{v} / \mathrm{v}$ & Bağıl katalaz aktivitesi (\%) & Organik çözücü & $\% \mathrm{v} / \mathrm{v}$ & Bağll katalaz aktivitesi (\%) \\
\hline $\begin{array}{l}\text { Negatif kontrol } \\
\text { (organik çözücü yok) }\end{array}$ & & 100 & $\begin{array}{l}\text { Negatif kontrol } \\
\text { (organik çözücü yok) }\end{array}$ & & 100 \\
\hline \multirow{4}{*}{ Etanol } & 2.5 & 98 & \multirow{4}{*}{ Aseton } & 2.5 & 59 \\
\hline & 5 & 87 & & 5 & - \\
\hline & 7.5 & 81 & & 7.5 & - \\
\hline & 10 & 44 & & 10 & - \\
\hline \multirow{4}{*}{ Metanol } & 2.5 & 45 & \multirow{4}{*}{ DMSO } & 2.5 & 49 \\
\hline & 5 & 25 & & 5 & 45 \\
\hline & 7.5 & 29 & & 7.5 & 33 \\
\hline & 10 & - & & 10 & 31 \\
\hline
\end{tabular}




\section{Tartışma ve Sonuç}

Küfler doğada hava, toprak, su ve organik maddeler üzerinde yaygın olarak bulunan çok hücreli ökaryotik mikroorganizmalardır. Bunlardan Aspergillus, nem içeren hemen her ortamda kolaylıkla gelişebilen ve yaklaşık 340 mantar türünden oluşmuş bir cinstir [36]. Doğadaki esas işlevi karbon ve nitrojen çevrimiyle ilgilidir, biyodegredasyonda da rol alır. Aspergillus'lar ekonomik, ekolojik ve tıbbi yönden önemlidirler [37]. Bunlardan A. niger ağırlıklı olarak büyük ölçekli enzim, organik asit ve biyoaktif bileşiklerin üretiminde kullanılmaktadır [36]. Bu nedenle $A$. niger, endüstriyel açıdan önemli bir suştur.

Genel olarak mantarlar tarafından üretilen katalazların kinetik ve biyokimyasal özellikleri hakkında literatürdeki bilgiler sınırlıdır. Son zamanlarda hidrojen peroksitin endüstride kullanımının artması, $\mathrm{H}_{2} \mathrm{O}_{2}$ 'nin su ve oksijene dönüștürülmesini sağlayan ekonomik ve kararlı katalaz enziminin üretilmeye çalışılmasını gerekli kılmıştır [38]. Yakın bir geçmişte termofilik bir mantar olan Scytalidium thermophilum tarafından büyümeye paralel olarak üretilen ve monofonksiyonel katalaz ailesine dahil olduğu kristal yapısı belirlenerek bulunan enzimin hidrojen peroksit yokluğunda çeşitli orto- ve para-difenolik bileşikleri okside ettiği rapor edilmiştir [15, 39]. Scytalidium katalazında gözlenen bu ikincil aktivitenin varlığı memeli katalazı [30] başta olmak üzere, Bacillus pumilus [32], Thermobifida fusca [33] ve Amaranthus cruentus [34-35] gibi mikrobiyal ve bitkisel kaynaklı katalazlarda da vurgulanmıştır. Ayrica Corynebacterium glutamicum ve insan eritrositleri gibi çeşitli kaynaklardan izole edilen ticari katalazlarda benzer oksidaz aktivite gözlenmiştir [15]. Buradan, ikincil aktiviteye sahip katalaz türü enzimlerin çok daha yaygın olabileceği, hatta insanda da olabileceği anlaşılmaktadır.

Bu çalışmada, mezofilik bir ökaryot olan A. niger'de üretilen katalazın saflaştırılması ve biyokimyasal özelliklerinin incelenmesi amaçlanmıştır. Buna göre öncellikle enzim kaynağı olarak kullanılan A. niger'in zamana bağlı katalaz üretimi analiz edildi. Elde edilen bulgular, $A$. niger'de büyümeye paralel olarak katalaz aktivitesinin arttığını; en yüksek değerine küfün durağan faza geçmesi ile ulaştığını göstermiştir (Şekil 1). Bu durum şaşırtıcı değildir; çünkü bilindiği gibi kesikli kültürlerde mikroorganizmalar substrat ve besin kaynakları ile oksijenin tüketilmesi sonucu durağan faza girerler. Bu sirada oksidatif stres varlığında çok sayıda reaktif oksijen türleri (ROS) oluşur $[40,41]$. Katalazlar ise antioksidan enzimler olup esas işlevleri stres varlığında hücrede meydana gelen bu ROS'ları ortamdan uzaklaştırmaktır [3]. Bu nedenle hücre büyümesi sırasında radikal üretiminin artmasına bağlı olarak baş edebildiği sürece katalaz aktivitesinin artması beklenir [42]. Ayrıca Escherichia coli tarafından üretilen monofonksiyonel katalaz HPII
(Hidroperoksidaz II) enzim sentezinin durağan fazda arttığını gösteren rapor, çalışma bulgularımızı destekler niteliktedir [43].

A. niger'de katalaz üretimini arttırmak için ısı şoku ve oksidatif stres denemeleri gerçekleştirildi. Çünkü enzim üretiminin bazı Aspergillus'larda oksidatif stres veya isı şokuna bağlı olarak hücrede artan $\mathrm{H}_{2} \mathrm{O}_{2}$ 'ye karşı savunma amacıyla arttığına dair raporlar bulunmaktadır [44, 45]. Çalışmada elde edilen bulgular, en yüksek katalaz aktivitesinin $37^{\circ} \mathrm{C}^{\prime}$ de büyütülen küfte ölçüldüğünü göstermektedir (Tablo 1). Bu sıcaklığın üzerinde aktivitede anlamlı bir düşüş gözlenmiştir. $45^{\circ} \mathrm{C}^{\prime}$ de aktivite optimum değere göre sadece $\% 31$ oranında azalırken $50^{\circ} \mathrm{C}$ ve üzerinde gelişme olmamasına bağlı olarak aktivite tamamen kaybolmuştur (Tablo 1). Mezofilik bir canlı olarak $A$. niger'in $50^{\circ} \mathrm{C}$ ve üzerinde büyümesinin durması beklenen bir durumdur. Literatürde katalaz kaynağ olarak kullanılan çeşitli Aspergillus suşlarıyla yapılan çalıșmalarda sıcaklık olarak genellikle $30^{\circ} \mathrm{C}$ tercih edilirken [14], bu çalışmada daha yüksek sıcaklıklarda $\quad\left(37-45^{\circ} \mathrm{C}\right) \quad$ katalaz üretimi gerçekleștirilmiștir. Yüksek sıcaklıklarda gelişen mikroorganizmalardan sıcaklığa dayanıklı enzimler üretilir [40]. Bu nedenle literatürde katalaz üreticisi olarak kullanılan Aspergillus'lara kıyasla daha yüksek sıcaklıkta büyütülebilen $A$. niger'in kullanılmasının ticari enzim uygulamalarında bir avantaj oluşturacağı önerilebilir.

Katalaz üretimi için oksidatif stres yaratmak üzere büyüme ortamına Bölüm 2.1'de belirtilen şekilde $\mathrm{H}_{2} \mathrm{O}_{2}$ eklendi. ROS olarak bilinen $\mathrm{H}_{2} \mathrm{O}_{2}$ 'nin test edilen hemen hemen tüm derișimlerinde negatif kontrole $\left(\mathrm{H}_{2} \mathrm{O}_{2}\right.$ 'siz ortam) göre daha düșük katalaz aktivitesi gözlendi (Şekil 2). Sadece $1 \mathrm{mM} \mathrm{H}_{2} \mathrm{O}_{2}$ 'nin eklendiği an $(\mathrm{t}=0)$ katalaz üretiminde negatif kontrole göre \%5'lik bir artış görüldü; ancak bu artış inkübasyonun ilerleyen zamanlarında kademeli olarak kayboldu. 1 mM derişimde diğer konsantrasyonlara göre aktivite daha yüksek ölçülmesine rağmen gözlenen bu artış negatif kontrolden daha düşük seviyededir. Bulgular, A. nidulans katalazı için rapor edilenden [45] farklı olarak, oksidatif stresin olumlu etkisinin olmadığını göstermektedir. Genel olarak peroksidaz aktivitesi gösteren katalazların oksidatif stres varlığında sentezinin tetiklendiği, diğer yandan monofonksiyonel katalazların $\mathrm{H}_{2} \mathrm{O}_{2}$ 'den etkilenmediğ bilinmektedir [43]. Bu durum çalışmada kullanılan $A$. niger katalazının monofonsiyonel katalaz ailesine dahil olabileceğine işaret etmektedir.

Katalaz enziminin $A$. niger'den saflaştırılmasında düşük maliyette ve yüksek verimle çalışan bir izolasyon yöntemi olarak tanımlanan TPP sistemi [6] kullanıldı. Bu sistemin tercih edilmesinin başlıca sebebi, enzimin ham örnekten tek basamakta saflaştırılmasını mümkün kılmasıdır. Literatürde katalaz enziminin saflaştırılması üzerine çok sayıda rapor mevcuttur. Ancak hepsinin ortak özelliği birden 
fazla aşamadan oluşmasıdır ki bu durum verimi azaltırken maliyeti yükseltir. Örneğin, Nerospora crassa katalazı asetonla çöktürme, ardından amonyum sülfatla çöktürme ve hidrofobik etkileşim kromatografisi (Fenil Sefaroz Kolonu ile) olmak üzere üç basamakta saflaştırılmıştır. Benzer şekilde, Septoria tritici katalazı diyaliz işlemini takiben iyon değişim kromatografisi (DEAE-C, DietilAminoEtil Selüloz) ve ardından hidrofobik etkileşim kromatografisi (Fenil Sefaroz Kolonu ile) kullanarak saflaştırılmıştır. S. thermophilum katalazının da yine üç basamakta (amonyum sülfatla çöktürme, iyon değişim ve jel filtrasyon kromatografileri) saflaştırıldığı rapor edilmiştir [14].

TPP sistemini etkileyen çok sayıda faktör bulunduğundan, proteinlerin karışık bir ortamdan etkili bir şekilde ayrılması için saflaştırma işlemini etkileyen her bir parametrenin ayrı ayrı incelenmesi gerekir [6]. Bu sebeple, katalaz enziminin ayrımını etkileyen parametreler (amonyum sülfat konsantrasyonu, ham ekstrakt:t-butanol oranı ve sistem pH'sı) sırayla incelendi. Hazırlanan sistemlerin hepsinde başlangıçta kullanılan örnekteki toplam protein miktarı $1 \mathrm{mg}$ (79 U katalaz aktivitesi içeren) olarak belirlendi ve enzimin işlem sonunda seçici bir şekilde ara fazda dağıldığı görüldü. Sistem parametrelerinin saflaștırma katsayısı ve aktivite geri kazanıma olan etkileri sirasıyla Tablo 2-4'de gösterilmektedir. Tablolardan görüldügü üzere, tüm parametreler katalaz enziminin $A$. niger'den saflaştırılmasında etkin rol oynamaktadır.

Amonyum sülfat konsantrasyonu, TPP sisteminde kritik bir öneme sahiptir. Dolayısıyla karışımdan katalaz enziminin yeterli miktarda ayrımı için optimize edilmesi gerekir. Bunun için genellikle \%20 (w/w) gibi minimum konsantrasyonda örnek çözeltisinin hazırlanmasıyla başlanır ve yavaş yavaş konsantrasyon arttırılarak istenilen protein ara fazda çöktürülmesi için optimizasyonu yapılır [6]. Tablo 2, farklı amonyum sülfat doygunluklarında hazırlanmış çözeltilerden (ham enzim ekstraktına eşit hacimde tbutanol eklenerek) ara faza ayrılmış olan katalaz enziminin saflaştırma analiz sonuçlarını göstermektedir. Buna göre, en yüksek saflaştırma katsayı (7.0) ve aktivite geri kazanım değeri (206) \%80 amonyum sülfat doygunluğunda hazırlanmış sistemden elde edilmiștir. TPP sistemlerinde enzim aktivasyonuna slklıkla karşılaşılmaktadır. Örneğin, pektinaz [8], peroksidaz [46], proteinaz $K$ [47] ve tripsin inhibitör [48] gibi proteinlerin sulu üçlü-faz sistemlerinden saflaştırılmaları sırasında katalitik aktivitelerinde artış gözlenmiştir. Bu durumun saflaştırma sırasında enzim molekülünün esnekliğinde meydana gelen artışla bağlantılı olabileceği açıklanmıştır. Düşük sulu çözeltilerde enzimin yapısında meydana gelen değişiklik enzim aktivasyonuna neden olabilmektedir [6].
Sisteme eklenen t-butanol miktarının da TPP'de önemli bir diğer faktör olması sebebiyle karışımdaki ham ekstrakt:t-butanol oranı optimize edildi. En iyi sonuçlar \%80 (w/w) amonyum sülfat doygunluğunda hazırlanan ve ham ekstrakt:t-butanol oranı 1.0:1.5 olan sistemden ölçüldü (Tablo 3). \%80 (w/w) amonyum sülfat içeren ve ham ekstrakt:t-butanol oranı $1.0: 0.5,1.0: 1.0$ ve $1.0: 2.0$ olacak şekilde hazırlanan sistemlerinden ise sirasıyla $2.0,7.0$ ve 5.9 kat enzim saflaştırılırken aktivite geri kazanım değerleri sırasıyla \%121, \%206 ve \%204 şeklinde belirlendi. Enzimi saflaştırmak amacıyla kullanılan TPP sistemlerinde, t-butanol ayırmada en iyi sonucu verdiği için genelde yardımcı organik çözücü olarak seçilmektedir. Ayrıca, t-butanolun büyük ve dallanmıș bir yapıya sahip olması sebebiyle katlanmış proteinin içine kolaylıkla giremeyeceği, dolayısıyla protein denatürasyonuna sebep olmayacağ düşünülmektedir [6]. Nitekim bu çalışmada tbutanolün katalaz aktivitesi üzerine herhangi bir olumsuz etkisi gözlenmemiştir.

Proteinlerin TPP sistemlerinde etkin bir şekilde çöktürülmesi sülfat konsantrasyonuna bağlı olduğu gibi proteinlerin net yüküne de bağlıdır. TPP sistemlerinde ham ekstrakt olarak farklı izoiyonik noktalara sahip bir protein karıșımının kullanılması durumunda, $\mathrm{pH}$ 'nın protein ayrımına etkisini tayin etmede pH'sı 3.0'den 7.0'ye kadar değișen sistemler hazırlanabilir [6]. Katalaz enziminin TPP sistemlerinde ayrımına pH'nın etkisi Tablo 4'te gösterilmiştir. Buna göre, pH 7.0'de hazırlanan sistemde katalaz karışımdaki diğer proteinlerden seçici bir şekilde ayrlarak ara faza geçmiştir. Diğer yandan, düşük ve yüksek pH'larda saflaştırma etkinliğinin oldukça düşük olduğu görülmektedir. Bu durum, $\mathrm{H}^{+}$(asidik koşullarda) veya $\mathrm{OH}^{-}$(bazik koşullarda) iyonlarının aşırı miktarlarda bulunması ile açıklanabilir. Bu iyonlar ortamda yüksek seviyede bulunduğunda karışımdaki katalaz enzimi ile yarışarak enzimin çözücü ile etkileşimini engelleyebilir ve sonuçta katalazın çözücüden uzaklaşarak orta faza geçmesini engellemiş olabilir [46].

Saflaştırılan katalaz enzim örneği SDS-PAGE ile analiz edildiğinde jel üzerinde tek bir bant gözlenmiş olup bu bant yaklaşık 87 kDa'ya denk gelmektedir (Şekil 3). $\mathrm{Bu}$ bulgu, çalışılan enzimin tipik bir monofonksiyonel katalaz olduğunu doğrular niteliktedir. Çünkü bu büyüklük değeri (87 kDa), büyük alt üniteli monofonksiyonel katalazlar için rapor edilen değer $(>75 \mathrm{kDa})$ aralığında yer almaktadır [49].

Saflaştırılmış enzimin karakterizasyonu için enzim aktivitesini ve dayanıklılığını etkileyen bazı parametreler seçilerek bunların etkileri analiz edildi. Karakterizasyon sonuçları Şekil 4-6 ve Tablo 5-6'da verilmektedir. 
Katalaz aktivitesine sıcaklığın etkisi $30-70^{\circ} \mathrm{C}$ sıcaklık aralığında incelenmiş olup enzimin optimum reaksiyon sıcaklı̆̆ $50^{\circ} \mathrm{C}$ olarak belirlendi(Şekil $4 \mathrm{~A}$ ). Ayrıca 40 ila $70^{\circ} \mathrm{C}$ gibi geniş sicaklık aralığında aktivitenin \%80'den fazlasının korunmuş olduğu gözlendi. Elde edilen bulgular literatürde katalaz için rapor edilen sıcaklık değerleri ile uyumludur. Genel olarak, farklı küf ve mayalardan izole edilen katalazlar için optimum reaksiyon sıcaklık aralığı 30 ila $85^{\circ} \mathrm{C}$ arasında değişmektedir [14].

Enzimin termal kararlılı̆̆ı, substratı bulunmayan bir ortamda enzimin sıcaklığa karşı yapısının bozulmadan kalması için gösterdiği direnci yansıtmaktadır. Katalaz enziminin termal kararlığını test etmek üzere enzim $30-70^{\circ} \mathrm{C}$ sıcaklık aralığında 60 dak süreyle inkübasyona maruz bırakıldıktan sonra rezidüel aktivitesi ölçüldü. Sonuçta, katalazın yüksek düzeyde kararlı kaldı̆̆ sıcaklık değerinin $40^{\circ} \mathrm{C}$ olduğu gözlendi. $\mathrm{Bu}$ sıcaklık değerin üzerinde ise aktivite hızlı bir șekilde optimum aktivite değerinin \%45'ine kadar düşüş gösterdi. Diğer yandan $50-70^{\circ} \mathrm{C}$ sıcaklık aralığında aktivitede önemli bir değişiklik olmamakla birlikte belirtilen sıcaklık aralığında $40^{\circ} \mathrm{C}$ 'de ölçülen aktivitenin \%55'inin hala korunmuş durumda olduğu bulundu (Şekil 4B). Bulgular, literatürle daha önceden yayınlanan raporlar ile uyumludur [14].

Katalaz aktivitesine pH'nın nasıl etki ettiğini gözlemlemek üzere ise saf enzim örneğinin pH'sı 4.0 ila 9.0 arasında değișen reaksiyon ortamlarında bağıl aktiviteleri ölçüldü (Şekil 5A). Buna göre katalaz için optimum reaksiyon $\mathrm{pH}$ değerinin 6.0 olduğu belirlendi. Ayrıca 4.0-7.0 pH aralı̆̆ında enzimin oldukça aktif olduğu görüldü; bu aralıkta enzimin başlangıç aktivitesinin \%50'sinden fazlası korunmuştur. A. niger katalazı için bulunan optimum pH değeri (6.0), bakterilerden Klebsiella pneumoniae ve Pseudomonad EF'den, mantarlardan ise Septoria tritici'den izole edilen katalazlarla benzerlik göstermektedir [14].

Enzimin pH kararlılığı analizi için saf enzim örneği pH'sı 4.0 ila 9.0 arasında değişen tampon çözeltilerde yaklaşık 60 dak inkübasyon bırakıldı ve akabinde bağıl aktiviteleri ölçüldü (Şekil 5B). Buna göre enzimin 6.0-7.0 pH aralığında oldukça aktif olduğu gözlendi. Belirtilen bu aralıkta başlangıç aktivitesinin \%96'dan fazlası korunmuştur. Ayrıca, pH 9.0'da başlangıçtaki aktivitenin \%77'si, pH 4.0 ve 5.0'te ise sırasıyla \%64 ve \%72'si korunmuştur. Buradan enzim aktivitesinin test edilen tüm pH'larda \%60'dan fazlasının korunduğu, dolayısıyla oldukça geniş bir $\mathrm{pH}$ aralığında enzimin bozunmadan kalabildiği görülmektedir. Enzimin farklı pH'larda kararlı özellik göstermesi endüstriyel uygulamalar açısından önemlidir. Süreçlerin uzamasından kaynaklı olarak ortam pH'sına uzun süre maruz kalabilecek bir enzim için bu parametre önem arz etmektedir [47].
Organik çözücüler proteinlerin fizikokimyasal özelliklerini değiştirme yeteneğine sahip bileşiklerdir. Genelde proteindeki kovalent olmayan bağlar, iyonik gruplar ve dipoller, hidrojen bağları ve hidrofobik etkileşimler gibi özellikleri değiştirirler. A. niger katalazının organik çözücülere olan dayanıklılığı Etanol $>$ DMSO $>$ Metanol $>$ Aseton şeklindedir (Tablo 5). Etanol, \%7.5'luk (v/v) derişime kadar reaksiyon ortamına konulabilirken diğer çözücüler aktivitede daha büyük kayıplara sebep olmaktadırlar.

Enzimin $\mathrm{K}_{\mathrm{m}}$ ve $\mathrm{V}_{\max }$ değerleri sırasıyla $21.4 \mathrm{mM}$ ve 20,000 $\mu \mathrm{mol} / \mathrm{dak} / \mathrm{l}$ (Şekil 6) olarak hesaplandı. Benzer $\mathrm{K}_{\mathrm{m}}$ değeri Neurospora crassa'dan (maya, 21.7 $\mathrm{mM}$ ) izole edilen katalazda da ölçülmüștür [50]. Ayrica bakterilerden Methanosarcina barkeri ve Oceanobacillus oncorhynchi katalazlarında $\mathrm{K}_{\mathrm{m}}$ değerleri sırasıyla 25 ve $24 \mathrm{mM}$ olarak bulunmuștur $[51,52]$. Katalaz enziminin çeşitli oksidaz/peroksidaz substratlarına olan ilgisini araștırmak amacıyla gerçekleşen spektrofotometri analizlerinde hidrojen peroksit yokluğunda 4-metil katekol ve katekolü okside edebildiği görüldü (Tablo 6). Diğer yandan guaiakol, hidrokinon, pirogallol, ABTS ve L-tirozin üzerinde herhangi bir etki gözlenmedi. Bu durum $A$. niger katalazının özellikle orto-difenolik bileşikler üzerinde etkili olduğuna ișaret etmektedir [22, 28, 39].

Basit, hızlı ve ekonomik bir yöntem olarak tanımlanan TPP sisteminin çeşitli endüstriyel uygulamalarda protein geri kazanımı açısından faydalı bir yöntem olduğu kanıtlanmıştır. Bu çalışmada, TPP sistemi kullanılarak ilk kez katalaz enzimi A. niger'den tek basamakta başarılı bir șekilde saflaștırılmıștır. Sistemden elde edilen katalaz enziminin geniş pH aralığında kararlı olması, etanole karşı göstermiş olduğu dayanıklılık ve ikincil oksidaz aktivite yetenekleri endüstriyel uygulamalarda iyi bir biyokatalizör olarak işlev görebileceği sinyalini vermektedir.

\section{Teşekkür}

$\mathrm{Bu}$ çalışma Kocaeli Üniversitesi Bilimsel Araştırma Projeleri Birimi (Proje No:2017/90) tarafindan desteklenmiştir. İstatistiksel analiz bulgularına katkılarından dolayı Dr. Arda Acemi'ye teșekkürlerimizi sunarız.

\section{Kaynakça}

[1] Switala, J., Loewen, P. C. 2002. Diversity of properties among catalases. Archives of Biochemistry and Biophysics, 401, 145-154.

[2] Calera, J. A., Sánchez-Weatherby, J., LópezMedrano, R., Leal, F. 2000. Distinctive properties of the catalase $\mathrm{B}$ of Aspergillus nidulans. FEBS Letters, 475, 117-120. 
[3] Hansberg, W., Salas-Lizana, R., Domínguez, L. 2012. Fungal catalases: function, phylogenetic origin and structure. Archives of Biochemistry and Biophysics, 525, 170-180.

[4] Paris, S., Wysong, D., Debeaupuis, J-P., Shibuya, K., Philippe, B., Diamond, R. D., Latge, J-P. 2003. Catalases of Aspergillus fumigatus. Infection and Immunity, 71, 3551-3562.

[5] Witteveen, C. F. B., Veenhuis, M., Visser, J. 1992. Localization of glucose oxidase and catalase activities in Aspergillus niger. Applied and Environmental Microbiology, 58, 1190-1194.

[6] Dennison, C., Lovrien, R. 1997. Three phase partitioning: concentration and purification of proteins. Protein Expression and Profication, 11, 149-161.

[7] Duman, Y., Kaya, E. 2014. Purification and recovery of invertase from potato tubers by three phase partitioning and determination of kinetic properties of purified enzyme. Turkish Journal of Biochemistry, 39, 443-448.

[8] Sharma, A., Gupta, M. N. 2001. Purification of pectinases by three-phase partitioning. Biotechnology Letters, 23, 1625-1627.

[9] Duman, Y., Kaya, E. 2013. Purification, recovery, and characterization of chick pea $\beta$ galactosidase in single step by three phase partitioning as a rapid and easy technique. Protein Expression and Purification, 91, 155160.

[10] Saxena, L., Iyer, B. K., Ananthanarayan, L. 2007. Three phase partitioning as a novel method for purification of ragi (Eleusine coracana) bifunctional amylase/protease inhibitor. Process Biochemistry, 42, 491-495.

[11] Roy, I., Gupta, M. N. 2002. Three-phase affinity partitioning of proteins. Analytical Biochemistry, $300,11-14$

[12] Şen, A., Eryılmaz, M., Bayraktar, H., Önal, S. 2011. Purification of $\alpha$-galactosidase from pepino (Solanum muricatum) by three-phase partitioning. Separation and Purification Technology, 83, 130-136.

[13] Roy, I., Sharma, A., Gupta, M. N. 2004. Threephase partitioning for simultaneous renaturation and partial purification of Aspergillus niger xylanase. Biochimica Et Biophysica Acta, 1698, 107-110.

[14] Sooch, B. S., Kauldhar, B. S., Puri, M. 2014. Recent insights into microbial catalases: isolation, production and purification. Biotechnology Advances, 32, 1429-1447.

[15] Yuzugullu, Y., Trinh, C. H., Smith, M. A., Pearson, A. R., Phillips, S. E. V., Sutay Kocabas, D., Bakir, U., Ogel, Z. B., McPherson, M. J. 2013. Structure, recombinant expression and mutagenesis studies of the catalase with oxidase activity from Scytalidium thermophilum. Acta Crystallogrographica Section D, 69, 398-408.

[16] Kacem-Chaouche, N., Destain, J., Meraihi, Z., Dehimat, L., Haddoum, T., Wathelet, J. P., Thonart, P. 2013. Optimization of extracellular catalase production from Aspergillus phoenicis K30 by a linear regression method using date flour as single carbon source and purification of the enzyme. African Journal of Biotechnology, 12, 2646-2653.

[17] Tian, Y. S., Xu, H., Peng, R. H., Yao, Q. H. 2013. Heterlogous expression and initial characterization of the peroxisomal catalase from the methylotropic yeast Hansenula polymorpha in Pichia pastoris. Applied Biochemistry and Microbiology, 49, 507-513.

[18] Garay-Flores, R. V., Segura-Ceniceros, E. P., De Leon-Gamez, R., Balvantin-Garcia, C., MartinezHernandez, J. L., Betancourt-Galindo, R., Ramirez, A. R. P., Aguilar, C. N., Ilyina, A. 2014. Production of glucose oxidase and catalase by Aspergillus niger free and immobilized in alginate-polyvinyl alcohol beads. The Journal of General and Applied Microbiology, 60, 262-269.

[19] Söyler, B. 2012. Characterization and analysis of the antioxidant capacity of functional phenolics oxidized by Scytalidium thermophilum catalase phenol oxidase (CATPO). Orta Doğu Teknik Üniversitesi, Fen Bilimleri Enstitüsü, Doktora Tezi, Ankara.

[20] Chang, Y. C., Tsai, H.-F., Karos, M., Kwon-Chung, K. J. 2004. THTA, a thermotolerance gene of Aspergillus fumigatus. Fungal Genetics and Biology, 41, 888-896.

[21] Kawasaki, L., Aguirre, J. 2001. Multiple catalase genes are differentially regulated in Aspergillus nidulans. Journal of Bacteriology, 183, 14341440.

[22] Ögel, Z. B., Yüzügüllü, Y., Mete, S., Bakir, U., Kaptan, Y., Sutay, D., Demir, A. S. 2006. Production, properties and application to biocatalysis of a novel extracellular alkaline phenol oxidase from the thermophilic fungus Scytalidium thermophilum. Applied Microbiology and Biotechnology, 71, 853-862.

[23] Bradford M. M. 1976. A rapid and sensitive method for the quantitation of microgram quantities of protein utilizing the principle of protein dye-binding. Analytical Biochemistry, 72, 248-254.

[24] Alici, E. H., Arabaci, G., 2016. Prufication of polyphenol oxidase from borage (Trachystemon orientalis L.) by using three-phase partitioning and investigation of kinetic properties. 
International Journal of Biological Macromolecules, 93, 1051-1056.

[25] Yuzugullu Karakus, Y., Isik, S. 2019. Partial characterization of Bacillus pumilus catalase partitioned in poly(ethylene glycol)/sodium sulfate aqueous two-phase systems. Preperative Biochemistry and Purification, 49, 391-399.

[26] Laemmli, U. K. 1970. Cleavage of structural proteins during the assembly of the head of bacteriophage T4. Nature, 227, 680-685.

[27] Blum, H., Beier, H., Gross, H. J. 1987. Improved silver staining of plant proteins, RNA and DNA in polyacrylamide gels. Electrophoresis, 8, 93-99.

[28] Kocabas, D. S., Bakir, U., Phillips, S. E. V., McPherson, M. J., Ogel, Z. B. 2008. Purification, characterization, and identification of a novel bifunctional catalase-phenol oxidase from Scytalidium thermophilum. Applied Microbiology and Biotechnology, 79, 407-415.

[29] Lineweaver, H., Burk, D. 1934. The determination of enzyme dissociation constants. Journal of American Chemical Society, 56, 65866.

[30] Vetrano, A. M., Heck, D. E., Mariano, T. M., Mishin, V., Laskin, D. L., Laskin, J. D. 2005. Characterization of the oxidase activity in mammalian catalase. The Journal of Biological Chemistry, 280, 35372-35381.

[31] Carrea, G., Riva, S. 2000 Properties and synthetic applications of enzymes in organic solvents. Angewandte Chemie International ed. in English, 39, 2226-2254.

[32] Sangar, S., Pal, M., Moon, L. S., Jolly, R. S. 2012. A catalase-peroxidase for oxidation of $\beta$-lactams to their (R)-sulfoxides. Bioresource Technology, $115,102-110$.

[33] Loncar, N., Fraaije, M. W. 2015. Not so monofunctional-a case of the thermostable Thermobifida fusca catalase with peroxidase activity. Applied Microbiology and Biotechnology, 99, 2225-2232.

[34] Chen, N., Teng, X.-L., Xiao, X.-G. 2017. Subcellular localization of a plant catalase-phenol oxidase, AcCATPO, from Amaranthus and identification of a non-canonical peroxisome targeting signal. Frontiers in Plant Science, 8, 1-11.

[35] Teng, X.-L., Chen, N., Xiao, X.-G. 2016. Identification of a catalase-phenol oxidase in betalain biosynthesis in red amaranth (Amaranthus cruentus). Frontiers in Plant Science, 6, 1228.

[36] Park, H.-S., Jun, S.-C., Han, K.-H., Hong, S.-B., Yu, J.-H. 2017. Chapter Three - Diversity, Application, and Synthetic Biology of Industrially Important
Aspergillus Fungi. Advances in Applied Microbiology, 100, 161-202.

[37] Asan, A. 2004. Aspergillus, Penicillium and related species reported from Turkey. Mycotaxon, 89, 155-157.

[38] Wang, H., Tokusige, Y., Shinoyama, H., Fujii, T., Urakami, T. 1998. Purification and characterization of a thermostable catalase from culture broth of Thermoascus auratiacus. Journal of Fermentation and Bioengineering 85, 169-173.

[39] Koclar Avci, G., Coruh, N., Bolukbasi, U., Ogel, Z. B. 2013. Oxidation of phenolic compounds by the bifunctional catalase-phenol oxidase (CATPO) from Scytalidium thermophilum. Applied Microbiology and Biotechnology, 97, 661-672.

[40] Bender, K. S. Buckley, D. H., Madigan, M. T., Martinko, J. M., Stahl, D. A. 2017. Brock Mikroorganizmaların Biyolojisi. Çeviri Editörü: Çökmüș, C. Ondördüncü baskıdan çeviri, Palme Yayınevi, Ankara, ISBN: 9786053555964.

[41] Lushchak, V. I. 2011. Adaptive response to oxidative stress: Bacteria, fungi, plants and animals. Comparative Biochemistry and Physiology Part C: Toxicology \& Pharmacology. $153,175-190$.

[42] Yüzügüllü, Y., Ögel, Z. B., Bakır Bölükbaşı, U., Coruh, N., Karakaș, G. 2011. Production of a novel bifunctional catalase-phenol oxidase of Scytalidium thermophilum in the presence of phenolic compounds. Turkish Journal of Biology, $35,697-704$.

[43] Mulvey, M. R., Switala, J., Borys, A., Loewen, P. C. 1990. Regulation of transcription of katE and $k a t F$ in Escherichia coli. Journal of Bacteriology, $172,6713-6720$.

[44] Noventa-Jordão, M. A., Couto, R. M., Goldman, M. H. S., Aguirre, J., Iyer, S., Caplan, A., Terenzi, H. F., Goldman, G. H. 1999. Catalase activity is necessary for heat-shock recovery in Aspergillus nidulans germlings. Microbiology, 145, 32293234.

[45] Kawasaki, L., Wysong, D., Diamond, R., Aguirre, J. 1997. Two divergent catalase genes are differentially regulated during Aspergillus nidulans development and oxidative stress. Journal of Bacteriology, 179, 3284-3292.

[46] Yuzugullu Karakus, Y., Acemi, A., Işık, S., Duman, Y. 2018. Purification of peroxidase from Amsonia orientalis by three-phase partitioning and its biochemical characterization. Separation Science and Technology, 53, 756-766.

[47] Singh, R. K., Gourinath, S., Sharma, S., Roy, I., Gupta, M. N., Betzel, C., Srinivasan, A., Singh, T.P. 2001. Enhancement of enzyme activity through three-phase partitioning: crystal structure of a 
modified serine proteinase at $1.5 \AA$ resolution. Protein Engineering, 14, 307-313.

[48] Wati, R. K., Theppakorn, T., Benjakul, S. Rawdkuen, S. 2009. Three-phase partitioning of trypsin inhibitor from legume seeds. Process Biochemisrty, 44, 1307-1314.

[49] Chelikani, P., Fita I., Loewen, P. C. 2004. Diversity of structures and properties among catalases. Cellular and Molecular Life Sciences, 61, 192-208.

[50] Diaz, A., Rangel, P., Oca, Y. M., Lledias, F., Hansberg, W. 2001. Molecular and kinetic study of catalase-1, a durable large catalase of Neurospora crassa. Free Radical Biology and Medicine, 31, 1323-1333.
[51] Calandrelli, V., Gambacorta, R. I., Carratore, V., Lama, L. 2008. A novel thermo-alkali stable catalase-peroxidase from Oceanobacillus oncorhynchi subsp. incaldaniensis: purification and characterization. World Journal of Microbiology and Biotechnology, 24, 2269-2275.

[52] Shima, S., Netrusov, A., Sordel, M., Wicke, M., Hartmann, G.C., Thauer, R. K. 1999. Purification, characterization and primary structure of a monofunctional catalase from Methanosarcina barkeri. Archives of Microbiology, 171, 317-323.

[53] Tauber, H. 1953. Oxidation of pyrogallol to purpurogallin by crystalline catalase. Journal of Biological Chemistry, 205, 395-400. 